\title{
EKSPLORASI KEMAMPUAN SISWA KELAS IV SEKOLAH DASAR DALAM PENYELESAIAN SOAL CERITA MATEMATIKA
}

\author{
V.A.N. Ariawan ${ }^{1}$, I.M. Pratiwi² \\ 1,2 Jurusan Pendidikan Dasar, \\ Universitas Pendidikan Indonesia, Indonesia \\ E-mail: vivianatsir@gmail.com ${ }^{1}$
}

\begin{abstract}
Abstrak
Penelitian ini bertujuan (1) untuk mengeksplorasi strategi siswa dalam penyelesaian soal cerita materi pengukuran; (2) untuk mengeksplorasi kesulitan belajar siswa dalam penyelesaian soal cerita. Partisipan dalam penelitian ini ialah 18 siswa kelas IV di SDN 2 Winduhaji, Kecamatan Kuningan. Pendekatan penelitian yang digunakan adalah kualitatif dengan metode studi kasus. Jenis data yang dikumpulkan berupa data kualitatif yaitu hasil penyelesaian soal cerita siswa. Teknik pengumpulan data dengan menggunakan tes, wawancara, dan analisis dokumen. Teknik analisis data menggunakan thematic analysis sedangkan validitas data menggunakan triangulasi, member checking, dan refleksivitas. Hasil penelitian menunjukkan bahwa strategi siswa dalam penyelesaian soal cerita yaitu (1) menggunakan bantuan gambar; (2) menggunakan bantuan diagram; (3) menerjemahkan masalah ke dalam operasi hitung penjumlahan, pengurangan, perkalian, atau pembagian. Kesulitan yang dialami siswa yaitu (1) kesulitan memahami masalah; (2) kesulitan merepresentasikan masalah ke bentuk matematika dan gambar; (3) kesulitan memahami konsep; (4) kesulitan membangun strategi penyelesaian; (5) gangguan kognitif siswa.
\end{abstract}

Kata kunci: kesulitan belajar, matematika, soal cerita, strategi

\begin{abstract}
The objectives for this research are (1) to explore student's strategies to solve story problem about measurement material; (2) to explore student's learning difficulties to solve story problem. Subject of this research were 18 of fourth grade students of SDN Winduhaji in Kuningan subdisctrict. This research using qualitative approach within case study method. Data in this research using qualitative namely result of story problem. Techniques of collecting data in this research are using test, interview, and document analysis. Data analyzed by using thematic analisys meanwhile data validated by using triangulation, member checking, and reflectivity. The results of this research show that student's strategies to solve story problem are (1) using pictures; (2) using diagram; (3) typed problem using addition, reduction, multiplication, and dividing operation. Student's learning difficulties to solve problem story are (1) problem comprehension difficulties; (2) difficult to representation the problem conductes math and pictures; (c) concept comprehension difficulties; (d) difficult to develop solving strategies; (e) student's cognitive disruption.
\end{abstract}

Keywords : learning difficulties, math, story problem, strategy

\section{PENDAHULUAN}

Salah satu keterampilan proses yang dimiliki siswa melalui pembelajaran matematika yang tercakup dalam standar proses yaitu pemecahan masalah. Pemecahan masalah matematis adalah suatu usaha mencari jalan untuk menyelesaikan dari suatu persoalan dalam matematika. Pemecahan masalah adalah cara berpikir, penalaran, dan menggunakan hal-hal yang dipelajari dalam semua kegiatan matematika (Aydoğdu, 2014; Huda \& Angle 2013).

Masalah didefinisikan sebagai bermacam tugas atau kegiatan yang 
mana siswa belum bisa menentukan aturan-aturan atau metode dan belum ada tanggapan dari siswa sehingga belum ada sebuah metode solusi yang tepat (Van De Walle, 2010). Menurut Haylock \& Anne (2013), masalah digunakan untuk untuk merujuk kepada kegiatan matematika pada dimensi open-ended yang melibatkan penerapan matematika pada situasi yang memiliki tujuan yang jelas. Suatu soal dapat dikatakan sebagai masalah jika soal tersebut memuat tantangan yang tidak dapat dikerjakan dengan prosedur rutin (Lenchner, dalam Khabibah \& Teguh, 2016). Permasalahan matematis berhubungan dengan masalah translasi, masalah aplikasi, masalah proses dan masalah teka-teki (Adji \& Maulana, 2006).

Soal cerita merupakan salah satu masalah matematis yang dikaitkan dengan kehidupan sehari-hari siswa. Soal cerita adalah soal matematika yang disajikan melalui media bahasa dengan banyak simbol dan notasi untuk menyampaikan masalah dan pemecahannya menggunakan pola pikir atau konsep matematika (Sumarwati, 2013). Inilah yang membedakannya dengan soal noncerita yang penyampaiannya langsung dalam bentuk simbol dan notasi matematika.

Seseorang dapat dikatakan memiliki kemampuan matematika apabila terampil dengan benar menyelesaikan soal matematika (Retna, dkk. 2013). Dilanjutkan oleh Dewi, dkk (2014) soal cerita matematika bertujuan agar siswa berlatih dan berpikir secara deduktif, dapat melihat hubungan dan kegunaan matematika dalam kehidupan sehari-hari, dan dapat menguasai keterampilan matematika serta memperkuat penguasaan konsep matematika. Erliani, dkk (2011) berpandangan bahwa soal cerita yang disajikan dengan bahasa yang sudah dikuasai siswa dengan baik, ternyata akan mempermudah siswa dalam mengubah ke model matematika. Kemudian Polya menjelaskan bahwa pemecahan masalah merupakan suatu aktivitas intelektual yang sangat tinggi sebab dalam pemecahan masalah siswa harus dapat menyelesaikan dan menggunakan aturan-aturan yang telah dipelajari untuk membuat rumusan (Alawiyah, 2014).

Kesalahan menyelesaikan soal cerita matematika terdiri dari kesalahan konsep, kesalahan pada langkah penyelesaian, dan/atau kesalahan pada hitung aljabar (Lestari dkk, 2010). Senada dengan White (2005) menyatakan prosedur analisis Newman bahwa "Process skills errors, the child identified an appropriate operation, or sequence of operations, but did not know the procedures necessary to carry out these operations accurately", maksudnya kesalahan terjadi ketika siswa dapat menentukan operasi yang harus dilakukan, tetapi tidak dapat menuliskan prosedur operasi tersebut.

Berbagai learning obstacle (kesulitan belajar) dalam penyelesaian soal cerita matematika muncul pada saat pembelajaran. Hal ini karena siswa fokus dalam mencari jawaban yang dianggap sebagai satu-satunya tujuan yang ingin dicapai. Dikarenakan fokus terhadap jawaban, siswa seringkali salah dalam memilih teknik penyelesaian yang benar. Kesulitan belajar dalam penyelesaian soal cerita matematika belum bisa dihindari oleh siswa manakala siswa tersebut tidak terbiasa untuk memecahkan suatu masalah matematis. Upaya-upaya awal dalam justifikasi oleh anak-anak akan melibatkan trial and error atau percobaan yang tidak sistematis pada banyak kasus (Wahyudin, 2008).

Kesalahan siswa terjadi disebabkan oleh soal yang diberikan berbeda dengan soal sebelumnya. Hal ini didukung dari hasil penelitian The National Assessment of Education Progress (NAEP) (2011) yang menyatakan bahwa, "tingkat keberhasilan siswa dalam penyelesaian masalah menurun drastis manakala konteks permasalahannya diganti dengan hal yang tidak dikenal".

Dalam penyelesaian soal cerita, beberapa siswa menggunakan berbagai cara atau strategi untuk memperoleh jawaban terbaik. Strategi siswa dalam penyelesaian soal cerita disebut 
sebagai learning trajectory. Menurut Simon (dalam Salimi, 2013) learning trajectory adalah lintasan belajar yang menggambarkan transformasi belajar yang dihasilkan dari partisipasi dalam aktivitas belajar matematika.

Terdapat tiga komponen utama learning trajectory, yaitu tujuan pembelajaran (learning goals), kegiatan pembelajaran (learning activities) dan hipotesis proses belajar siswa (hypothetical learning process). Tujuan pembelajaran merupakan bentuk hasil yang ingin tercapai setelah proses pembelajaran. Tujuan pembelajaran akan tercapai setelah kegiatan pembelajaran (learning activities), sehingga kegiatan pembelajaran merupakan jalan untuk mencapai tujuan tersebut. Sementara itu, hipotesis proses belajar (hipothetical learning process) siswa dibuat sebagai tindakan atau strategi alternatif dalam mengatasi berbagai masalah siswa yang mungkin terjadi selama proses pembelajaran.

$$
\text { Penelitian tentang analisis }
$$

learning trajectory telah dilakukan sebelumnya oleh Salimi (2013) pada siswa kelas rendah sekolah dasar. Salimi melakukan penelitian tentang "Analisis learning trajectory matematika dalam konsep penjumlahan pada siswa kelas rendah sekolah dasar". Hasil penelitian ini menunjukkan bahwa terdapat tiga pola learning trajectory yang ditemukan pada penyelesaian soal oleh siswa kelas rendah sekolah dasar yaitu pola langsung prosedural atau abstrak, pola menggunakan gambargambar atau semi abstrak, dan pola menggunakan benda-benda konkret.

Penelitian selanjutnya terkait analisis learning trajectory dilakukan oleh Mutaqin (2013) dalam konsep perkalian bilangan cacah di kelas rendah sekolah dasar. Hasil penelitian Mutaqin menunjukkan bahwa terdapat tiga pola learning trajectory yang ditemukan dalam konsep perkalian bilangan cacah pada siswa kelas rendah sekolah dasar berupa pola langsung prosedural atau abstrak, pola menggunakan gambar-gambar atau semi abstrak, pola menggunakan benda-benda konkret, dan menghapal.
Namun, selain tiga pola tersebut ada beberapa siswa yang melakukan penghitungan dengan cara menghapal pola perkalian secara runtut.

Berdasarkan pemaparan sebelumnya, peneliti tertarik melakukan penelitian dengan tujuan untuk mengeksplorasi strategi siswa dalam penyelesaian soal cerita materi pengukuran dan kesulitan belajar yang dihadapi siswa dalam penyelesaian soal cerita.

\section{METODE}

Penelitian ini menggunakan pendekatan kualitatif dengan metode studi kasus. Metode studi kasus dipilih agar dapat menjawab pertanyaan penelitian yang diajukan, yaitu untuk mengeksplorasi strategi siswa dalam penyelesaian soal cerita materi pengukuran, kesulitan belajar yang dihadapi siswa dalam penyelesaian soal cerita, dan alternatif untuk mengatasi kesulitan tersebut. Metode studi kasus berguna untuk mengeksplorasi isu maupun fenomena secara mendalam dalam konteks yang natural dengan menggunakan berbagai teknik pengumpulan data (Crowe, dkk., 2011).

Penelitian ini dilaksanakan pada siswa kelas IV SDN Winduhaji di Kecamatan Kuningan dengan siswa sebanyak 18 orang. Data dalam penelitian studi kasus dikumpulkan melalui beberapa teknik pengumpulan berupa tes, observasi, dan wawancara. Hal ini dilakukan agar data-data yang diperoleh selama penelitian memiliki validitas yang kuat.

Teknik pengumpulan data yang pertama yaitu tes yang digunakan untuk menganalisis strategi penyelesaian soal cerita oleh siswa. Teknik pengumpulan data yang ke dua yaitu wawancara. Wawancara dilakukan oleh peneliti untuk menggali informasi secara lebih mendalam terkait dengan kesulitan membaca yang dialami siswa. Narasumber dari wawancara ini ialah siswa kelas IV sekolah dasar. Wawancara akan dilaksanakan secara informal melalui pertanyaan terbuka kemudian peneliti mencatat jawaban partisipan. Wawancara secara informal 
merupakan wawancara yang dilakukan secara wajar seperti perbincangan sehari-hari secara santai dan cair dalam konteks alamiah (Putra \& Dwilestari, 2012).

Teknik pengumpulan data yang ketiga yaitu analisis dokumen. Dokumen yang akan dianalisis yaitu hasil tes siswa. Dokumen berperan sebagai sumber pelengkap dan pemerkaya bagi informasi yang diperoleh lewat wawancara dan observasi (Alwasilah, 2009). Melalui dokumen, peneliti dapat menganalisis strategi penyelesaian soal cerita yang dikerjakan siswa.

Analisis data dalam penelitian ini menggunakan pendekatan kualitatif dengan teknik thematic analysis atau analisis tematik. Naughton dan Hughes (2009) menyatakan bahwa analisis tematik merupakan teknik analisis data yang dilakukan dengan cara melihat dan menemukan tema-tema dan kategori yang diperoleh dalam data yang telah dikodekan terlebih dahulu. Tahapan analisis data dalam penelitian ini yaitu (1) menyiapkan data mentah; (2) membaca keseluruhan data; (3) mengcoding data; (4) menghubungkan hasil coding; (5) menginterpretasi hasil coding (Creswell, 2013).

Validitas dan reliabilitas merujuk pada masalah kualitas data dan ketepatan metode yang digunakan untuk melaksanakan penelitian. Alwasilah (2009) mengungkapkan bahwa kualitas data dan ketepatan metode yang digunakan untuk melaksanakan penelitian sangat penting terutama pada ilmu-ilmu sosial karena pendekatan filosofis dan metodologis yang berbeda terhadap studi aktivitas manusia. Untuk menguji validitas data dalam penelitian ini peneliti menggunakan triangulasi, member checking, dan refleksivitas.

Triangulasi merupakan suatu proses pemanfaatan persepsi yang beragam untuk mengklarifikasi makna, memverifikasi kemungkinan pengulangan dari suatu observasi atau interpretasi dengan prinsip tidak ada observasi dan interpretasi yang dapat diulang (Denzin \& Lincoln, 2009).
Triangulasi merujuk pada pengumpulan informasi sebanyak mungkin dari berbagai sumber melalui berbagai metode (Cohen, Manion, \& Marison, 2007). Penelitian ini menggunakan triangulasi jenis data yang diperoleh dari hasil wawancara dan analisis dokumen. Member checking merupakan teknik menguji validitas data untuk (1) menghindari salah tafsir terhadap jawaban responden sewaktu wawancara; (2) menghindari salah tafsir terhadap perilaku responden sewaktu diobservasi; (3) mengkonfirmasi perspektif responden terhadap suatu proses yang sedang berlangsung (Alwasilah, 2009).

Refleksivitas mengacu pada kesadaran peneliti dalam memosisikan diri pada tulisannya dimana peneliti sadar akan bias, nilai, dan pengalaman yang dia bawa (Creswell, 2015). Peneliti sangat penting untuk tidak hanya menerangkan pengalamannya dengan fenomena yang sedang diteliti tetapi peneliti juga menyadari bahwa pengalaman ini sangat mungkin memengaruhi temuan, kesimpulan, dan penafsirannya dalam penelitian. Peneliti harus menjaga sikap, menunjukkan persahabatan, dan berusaha tak terlihat di kelas agar pembelajaran berjalan natural atau tidak dibuat-buat. Peneliti tidak berhak ikut campur dan memaksa partisipan untuk melakukan kegiatan yang dikehendaki peneliti.

\section{HASIL DAN PEMBAHASAN}

Berdasarkan tes yang sudah dilakukan, tidak semua soal dianalisis, hanya lima soal saja yang mewakili berbagai strategi yang dilakukan siswa dalam menjawab soal. Hasil tes dan wawancara dipaparkan sebagai berikut.

\section{a. Soal Nomor 1}

Hari ini siswa kelas IV akan melakukan tes kesegaran jasmani. Tes yang akan dilakukan siswa berupa tes lari 100 meter. Siswa melakukan tes lari secara bergilir. Berikut ini merupakan tabel waktu yang ditempuh lima siswa dalam menyelesaikan lari 100 meter. 
Tabel 1. Waktu tempuh siswa dalam menyelesaikan lari 100 meter

\begin{tabular}{ll}
\hline Nama & Waktu \\
\hline Aldi & 19 detik \\
Barra & 22 detik \\
Chairul & 26 detik \\
Dani & 18 detik \\
Eka & 24 detik \\
\hline
\end{tabular}

a. Siapakah yang berlari lebih cepat?

b. Berapakah perbedaan waktu berlari Chairul dan Aldi?

Berdasarkan soal nomor 1, pada poin a terdapat 11 siswa menjawab benar dan 8 siswa menjawab salah. Sedangkan, pada poin b terdapat 9 siswa menjawab benar, 7 siswa menjawab salah, dan 2 siswa tidak menjawab. Siswa memiliki berbagai strategi untuk menyelesaikannya. Berikut hasil analisis dan wawancara siswa.

1) Cara 1: Siswa melihat tabel untuk menemukan informasi waktu yang paling sedikit yaitu Aldi 18 detik. Dengan demikian, dia memperoleh jawaban siapa yang berlari lebih cepat. Hal ini merujuk siswa pada jawaban yang benar.

2) Cara 2: Siswa melihat tabel untuk menemukan informasi pada kolom dengan waktu yang paling banyak yaitu Chairul 26 detik. Siswa yang mengerjakan seperti ini merupakan siswa yang keliru. Dia berpikir bahwa yang memiliki waktu paling banyak adalah yang menjadi pemenang dalam lomba lari. Untuk itu, guru perlu memberikan pertanyaan arahan pada siswa.

Berikut ini merupakan transkrip wawancara oleh peneliti dengan siswa,

$P$ : "Kalau kita mengikuti lomba lari supaya kita menang kita harus lebih cepat atau lebih lambat?"

S: "Lebih cepat bu".

$P$ : "Kalau lebih cepat, waktunya lebih banyak atau lebih sedikit?"

S: "Berarti lebih sedikit bu kan lebih sebentar, ehh nu kamari salah nya bu (eh yang kemarin salah ya bu?)?"

$P$ : "Nah berarti seharusnya siapa yang berlari lebih cepat?"
S: "Kuduna mah jawabanna teh Dani bu (seharusnya jawabannya Dani), kan Dani waktunya 18 detik."

3) Cara 3: Siswa melihat tabel untuk menemukan informasi pada kolom dengan waktu yang paling sedikit. Namun, siswa ini keliru. Ketika melihat tabel, dia langsung melihat baris pertama sehingga memperoleh data bahwa yang berlari lebih cepat adalah Aldi dengan waktu 19 detik.

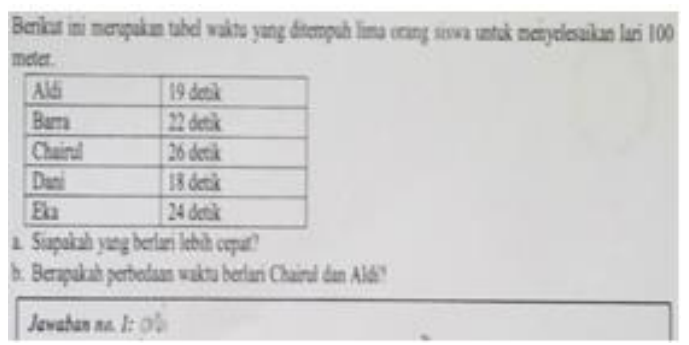

Gambar 1. Jawaban Siswa A

Dalam hal ini, peneliti memberikan pertanyaan arahan sebagai berikut,

$P$ : "Kenapa ini jawabannya Aldi yang paling cepat berlari?"

S: "Kan ini Aldi 19 detik, nu sanesna 22 detik. Berarti Aldi nu cepat (Kan Aldi 19 detik, yang lainnya 22 detik. Berarti Aldi yang cepat)".

P: "Tingali deui ka handapna (lihat lagi ke bawahnya), ada yang lebih kecil gak waktunya?"

S: "ih iya bu, Dani lebih kecil kan 18 detik hehehe salah bu".

$P$ : "Kunaon geuning tiasa lepat? (Kenapa bisa salah?) Tidak teliti ya?"

S: "Hehehe... muhun bu (iya bu)".

Berdasarkan hasil pekerjaan siswa untuk nomor 1 poin a hanya terdapat satu cara yang ditempuh oleh siswa untuk memperoleh jawaban yang tepat yaitu cara 1 dengan melihat tabel. 
Analisis jawaban dan wawancara pada poin b adalah sebagai berikut.

1) Cara 1: Siswa melihat waktu yang ditempuh Chairul yaitu 26 detik dan waktu yang ditempuh Aldi yaitu 18 detik. Kemudian melakukan operasi hitung pengurangan menggunakan konsep yang sebelumnya didapatkan siswa mengenai selisih adalah bilangan yang besar dikurangi dengan bilangan lain yang lebih kecil. Oleh sebab itu, siswa menghitung waktu yang ditempuh Chairul dikurangi waktu yang ditempuh Aldi, karena Chairul menempuh waktu lebih banyak dari Aldi. Berikut adalah contoh hasil pekerjaan siswa,

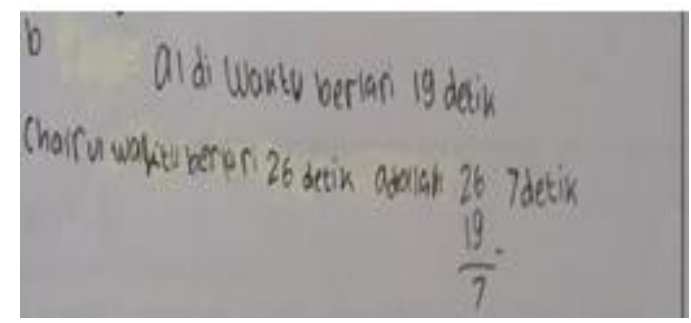

Gambar 2. Jawaban Siswa B

2) Cara 2: Siswa melihat waktu yang ditempuh Chairul yaitu 26 detik dan waktu yang ditempuh Aldi yaitu 18 detik. Kemudian menuliskan bilangan dari 26 sampai 18 seolah-olah seperti grafik. Selanjutnya siswa membilang dari 26 sampai 18 dan seharusnya siswa memperoleh jawaban 7, karena jarak dari 26 sampai 18 sudah melompati 7 bilangan lainnya.

Namun, sangat disayangkan terdapat kekeliruan hasil pekerjaan siswa tersebut. Siswa membilang dimulai dari bilangan 25 dan berhenti di bilangan 19. Dia keliru dengan pekerjaannya sendiri karena dia melingkari bilangan 25 dan 19 sebagai tanda batas dan dia lupa untuk membilang bilangan 19. Berikut adalah hasil pekerjaan siswa,

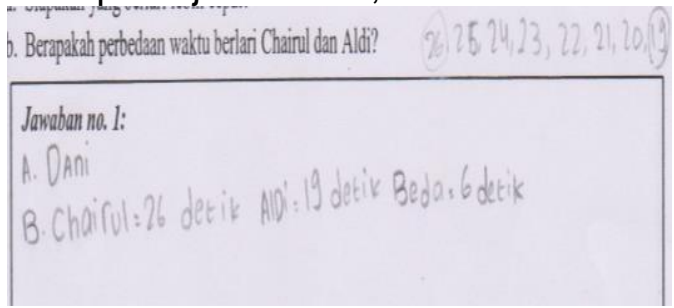

\section{Gambar 3. Jawaban Siswa C}

Untuk memperoleh klarifikasi jawaban siswa, peneliti melakukan wawancara. Berikut adalah transkrip wawancara dengan siswa,

$P$ : "Pekerjaannya sudah betul caranya tapi ko hasilnya 6 detik yah? Ini dapat 6 nya dari mana?"

S: "Dihitung bu".

$P$ : "Gimana cara ngitungnya?"

S: "Gini 25, 24, 23, 22, 21, 20. Jadi ada 6 kan?" (sambil menggerakkan jarinya)

P: "Ko bilangan 19 nya gak ikut dihitung?"

S: "Eh iya yah, bu. Ihh aku salah melingkarinya bu, jadi bingung. Harusnya aku ngga ngelingkari yang ini". (menunjuk ke bilangan 19)

P: "Coba hitung lagi ada berapa kali loncatan!"

3) Cara 3: Siswa membilang menggunakan jarinya mulai dari bilangan 20 sampai 25 sehingga memperoleh jawaban 6. Kekeliruan ini terjadi sama halnya dengan kekeliruan pada siswa yang menggunakan cara nomor 2 yaitu kurangnya ketelitian siswa dalam membilang.

4) Cara 4: Siswa melihat waktu yang ditempuh Chairul yaitu 26 detik dan waktu yang ditempuh Aldi yaitu 18 detik. Kemudian melakukan operasi hitung penjumlahan. Siswa belum memahami konsep selesih. Kekeliruan ini terjadi pada beberapa siswa lainnya.

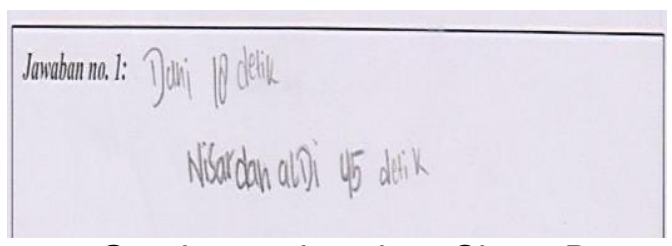

Gambar 4. Jawaban Siswa D

Setelah melihat jawaban siswa, selanjutnya peneliti melakukan wawancara dengan transkrip berikut ini, P: "Dapat jawaban 45 dari mana?"

S: "Waktu Chairul ditambah waktu Aldi, 26 ditambah 19 jadi 45"

P: "Mengapa bisa ditambah?" 
S: "Hmmm ngarang bu, kan biasanya juga kalo ada angka mun teu ditambah nya dikurangi (kan biasanya juga kalo ngga ditambah, ya dikurangi)".

$P$ : "Kenapa milih yang ditambah bukan dikurangi?"

S: "Ngasal bu hehehe"

$P$ : "Hmmm, coba baca di soal kan ditanyakan perbedaan waktu, nah yang seperti itu namanya selisih, jadi kamu harus mengurangkan bilangan yang lebih besar dengan bilangan yang lebih kecil. Misalnya Amir memperoleh nilai ulangan 9, sedangkan Bani memperoleh nilai ulangan 6 , berapa perbedaan nilai ulangan Amir dan Bani?"

S: "Dikurangi ya bu? 9-6 = 3 bu"

$P$ : "lya benar. Jadi kalau perbedaan waktu Chairul dan Aldi dalam berlari berapa?"

S: "26 - $19=6$ " (melakukan operasi hitung pengurangan bersusun)

$P$ : "Jadi, nanti kalo kamu menemukan soal seperti ini lagi bisa kan ngerjainnya?"

S: "lya bu, insya Allah bisa".

Berdasarkan keempat cara yang ditempuh siswa untuk nomor 1 poin $b$, dengan demikian terdapat dua cara yang ditempuh oleh siswa untuk memperoleh jawaban yang tepat yaitu cara 1 dan cara 2.

\section{b. Soal Nomor 2}

Untuk mengerjakan satu soal matematika, Adila membutuhkan waktu 5 menit. Jika Adila diberi 12 soal matematika, berapa waktu yang diperlukan Adila untuk menyelesaikannya?

Berdasarkan soal nomor 2, terdapat 15 siswa menjawab benar dan 3 siswa menjawab salah. Siswa memiliki berbagai strategi untuk menyelesaikannya. Berikut hasil analisis dan wawancara siswa,

1) Cara 1: Siswa menerjemahkan soal menjadi operasi hitung penjumlahan berulang. Dia menjumlahkan bilangan 5 sebanyak 12 kali. Cara seperti ini dilakukan oleh tiga orang siswa.

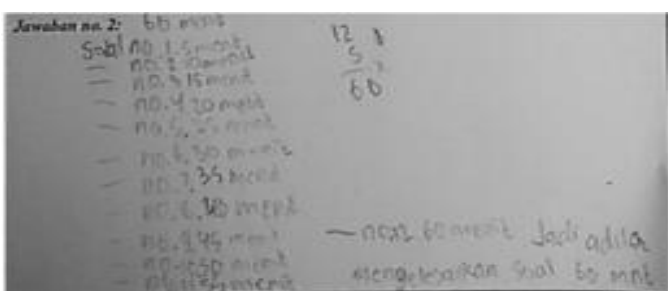

Gambar 5. Jawaban Siswa E

Peneliti mengajukan pertanyaan untuk mengarahkan siswa memahami konsep perkalian, misalnya, "Apakah ada cara lain untuk menjumlahkan angka 5 sebanyak 12 kali?' sampai siswa memahami bahwa soal seperti ini dapat dikerjakan dengan menggunakan konsep perkalian.

2) Cara 2: Siswa menerjemahkan soal menjadi operasi hitung perkalian. Dengan demikian, jika satu soal memerlukan waktu 5 menit, maka untuk 12 soal membutuhkan waktu (5 $x$ 12) menit yaitu 60 menit atau satu jam. Cara seperti ini dilakukan oleh 12 orang siswa.

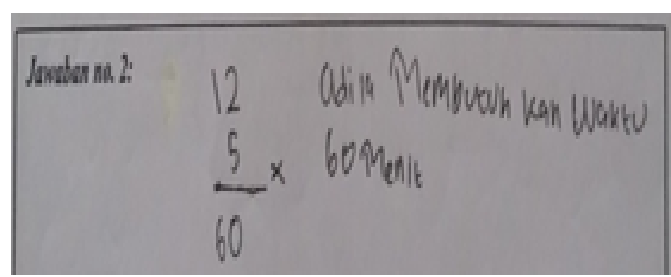

Gambar 6. Jawaban Siswa F

3) Cara 3: Siswa menerjemahkan soal menjadi operasi hitung pengurangan. Dia mengurangkan bilangan 12 dengan 5 sehingga diperoleh hasil 7 menit

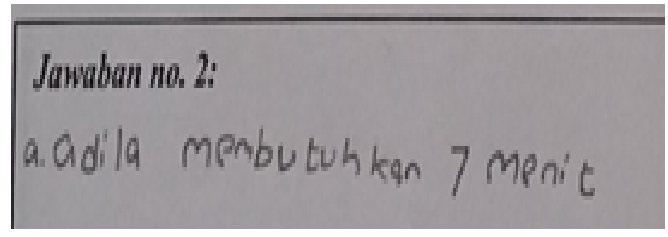

Gambar 7. Jawaban Siswa G

Siswa hanya menuliskan "Adila membutuhkan 7 menit" pada lembar jawaban dan tidak ditemukan coretan dari mana ia memperoleh jawaban tersebut. Oleh karenanya, peneliti melakukan wawancara terhadap siswa dengan transkrip sebagai berikut, 
P: "Coba jelaskan dari mana kamu memeroleh hasil 7 menit!"

S: "Hmmm lupa lagi bu, gak tau".

$P$ : "Lha, ko gak tau? Kan ini hasil pekerjaannmu. Coba baca lagi soalnya!"

S. "Kalo gak salah 12 dikurangi 5 jadi 7 jawabannya".

$P$ : "Mengapa dikurangi?"

S: "Ngasal bu hehehe".

P: "Kan Adila membutuhkan waktu 5 menit untuk 1 soal, kalau 2 soal jadi waktu yang dibutuhkan Adila berapa?"

S: (menghitung menggunakan jari) "jadi 10 menit bu".

$P$ : "Kalau 3 soal, waktunya berapa?"

S: "10 ditambah 5 jadi 15 "

P: "Nah terus begitu sampai 12 soal, jadi nanti kamu akan memperoleh jawabannya. Coba berapa?"

S: (menghitung dengan penjumlahan berulang dan memperoleh hasil 60)

4) Cara 4: Siswa menulis sembarang vbilangan. Kemudian peneliti mewawancarai siswa tersebut. Setelah ditelusuri, ternyata dia merupakan siswa yang belum bisa membaca. Adapun pada jawaban sebelumnya pada nomor 1 merupakan hasil meniru jawaban temannya.

Siswa lainnya juga menjawab dengan sembarang bilangan. Namun, setelah diwawancarai, dia menjelaskan bahwa dia kekurangan waktu dalam mengerjakan. Untuk mengisi jawaban yang belum sempat dikerjakan, dia menuliskan sembarang bilangan. Berikut adalah contoh pekerjaan siswa yang menjawab dengan asal,

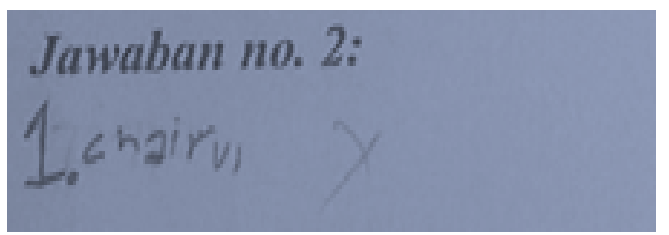

Gambar 8. Jawaban Siswa H

\section{c. Soal Nomor 4}

Nazwa membeli 453 gram strawberry. Dia menggunakan strawberry tersebut untuk membuat jus sehingga bersisa 23 gram strawberry. Berapa gram strawberry yang digunakan Nazwa untuk membuat jus?

Berdasarkan soal nomor 4, sebanyak 11 siswa dapat menjawab dengan benar dan 7 lainnya menjawab salah. Siswa memiliki berbagai strategi untuk menyelesaikannya. Berikut hasil analisis dan wawancara siswa,

1) Cara 1: Siswa menerjemahkan soal menjadi operasi hitung pengurangan. Dengan demikian diperoleh jawaban bahwa strawberry yang digunakan Nazwa untuk membuat jus adalah 430 gram. Cara seperti ini dilakukan oleh enam orang siswa.

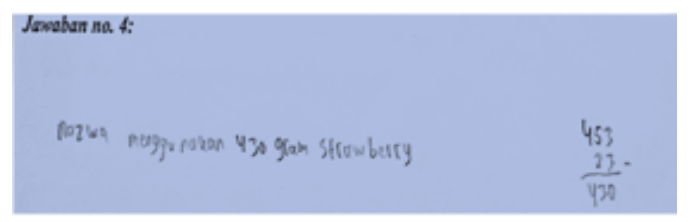

Gambar 9. Jawaban Siswa I

2) Cara 2: Siswa menerjemahkan soal menjadi operasi hitung pengurangan. Uniknya, dalam operasi hitung pengurangan yang digunakan oleh siswa tersebut justru bilangan pengurangnya merupakan jawaban dari masalah yang diajukan. Berikut ini adalah pekerjaan siswa menggunakan cara 2 ,

\section{Gambar 10. Jawaban Siswa J}

Setelah dilakukan wawancara terhadap siswa, diperoleh informasi bahwa siswa tersebut sudah menghitung jawabannya dan memperloleh jawaban 430 gram. Kemudian untuk mengecek kebenaran, maka siswa melakukan pengurangan 453 dikurangi 430.

$P$ : "Ari ieu jawabanna nu leres nu mana (kalau ini jawaban yang betul yang mana)?" (menunjuk ke jawaban siswa) 
S: "Sakedap bu, abi baca deui soalna. Abina hilap (sebentar bu, saya baca lagi soalnya. Saya lupa)".

$P$ : "lya dibaca dulu aja!"

S: "Ih bu, yang benernya ge $430 \mathrm{gram}$ (Bu, jawaban yang betul 430".

$P$ : "Geuning ieu kunaon jawabanna 23 gram? Kalah 453 dikurangi 430? (Kenapa jawabannya 23 gram? Kenapa 453 dikurangi 430)"

S: "Kan abi teh tos ngerjakeun bu, tah jawabanna teh 430. Trus ku abi dicek deui jawabanna jadi 453$430=23$. Tuh kan sami jawabanna sareng na soal (Kan saya sudah mengerjakan, jawabannya 430. Lalu saya mengecek kembali jawabannya jadi 453-420=23. Tuh kan jawabannya sama dengan yang di soal."

$P$ : "Oh gitu, jadi jawabannya berapa yang betul?"

S: "430 gram bu".

3) Cara 3: Siswa menerjemahkan soal menjadi operasi hitung pengurangan. Namun, siswa mengalami kekeliruan. Siswa tersebut mengurangkan bilangan 453 dengan 430 namun memperoleh jawaban yang kurang tepat. Terdapat dua siswa yang melakukan pekerjaan demikian.

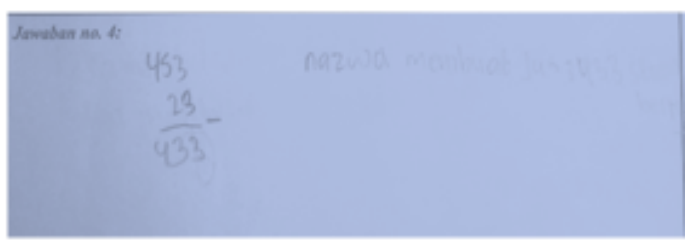

Gambar 11. Jawaban Siswa K

Selanjutnya, peneliti melakukan wawancara untuk mengklarifikasi jawaban siswa. berikut ini transkrip wawancara dengan siswa,

P: "Coba hitung kembali jawaban punyamu!"

S: (menghitung jawaban) "salah bu, harusnya 430"

$P$ : "Lalu kenapa waktu itu jawabnya 433? Gak teliti ya?"

S: "Iya bu, buru-buru ngerjainnya takut ga sempet ngerjain soal yg lain"
P: "Lain kali harus teliti yah. Caranya sudah betul tapi kalau hasilnya salah tetap saja kurang sempurna pekerjaannya".

4) Cara 4: Siswa menerjemahkan ke dalam operasi hitung penjumlahan. Terdapat dua orang siswa yang melakukan dengan cara ini.

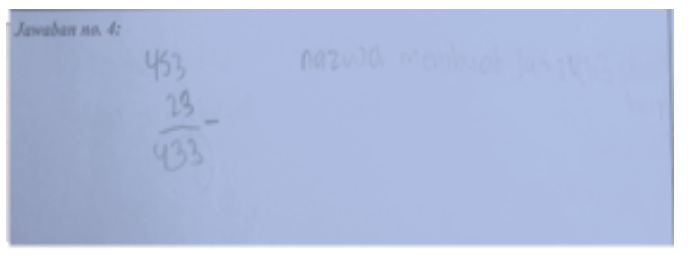

Gambar 12. Jawaban Siswa L

Kemudian peneliti melakukan wawancara untuk mengklarifikasi jawaban siswa sebagai berikut,

$P$ : "S mengerti ngga maksud soal ini?"

S: "Henteu bu (tidak bu)".

P: "Nazwa pertamanya beli 453 gram, terus Nazwa membuat jus. Setelah membuat jus, ternyata masih ada sisa 23 gram strawberry. Terus sisanya berapa?"

S: "Oh jadi misalnya saya beli strawberry terus saya buat jus nah strawberry nya sisa berapa, gitu kan bu?"

P: "lya betul, gimana coba?"

S: "Dikurangi bukan bu?"

$P$ : "Nah, jawabannya berapa?"

S: (menghitung) "430 bu, kadang saya ngga ngerti bu kalo soal cerita".

$P$ : "Kenapa ngga ngerti?"

S: "Harus dijelasin ibu dulu biar ngerti".

$P$ : "Oh gitu? Kalo mengerjakan sendiri ngga bisa?"

S: "Ngga bisa bu, apalagi soalnya pake bahasa Indonesia".

$P$ : "Barusan sudah ibu jelaskan ngerti?"

S: "Ngerti bu".

5) Siswa menuliskan sembarang bilangan seperti soal sebelumnya.

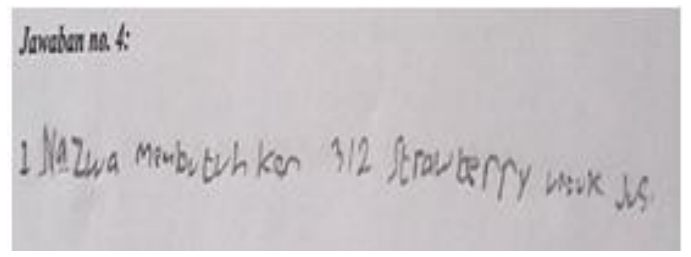

Gambar 13. Jawaban Siswa M 
Jawaban di atas dikerjakan oleh siswa yang sama pada soal sebelumnya. Siswa menjawab dengan sembarang karena kekurangan waktu.

\section{d. Soal nomor 6}

Refa membutuhkan waktu 15 menit untuk menyelesaikan soal matematika. Putra membutuhkan waktu 7 menit lebih banyak dari Refa untuk menyelesaikan soal matematika. Berapakah total waktu yang dibutuhkan oleh keduanya?

Berdasarkan soal nomor 6, terdapat tiga siswa menjawab benar, 14 siswa menjawab salah, dan 1 siswa tidak menjawab. Berikut hasil analisis dan wawancara siswa mengenai berbagai strategi yang digunakan,

1) Cara 1: Siswa mencari waktu yang dibutuhkan oleh Putra untuk menyelesaikan soal dengan cara melakukan operasi hitung penjumlahan waktu yang dibutuhkan Refa dengan selisih waktu yaitu 15 ditambah 7 sehingga hasilnya 22 menit. Kemudian siswa menjumlahkan waktu yang dibutuhkan Refa dengan waktu yang dibutuhkan Putra yakni 15 menit ditambah 22 menit, hasilnya adalah 37 menit. Cara seperti ini dilakukan dengan baik oleh tiga orang siswa.

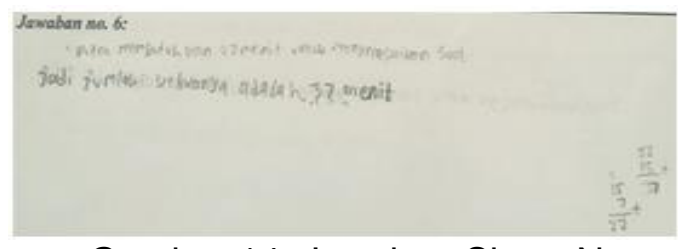

Gambar 14. Jawaban Siswa N

2) Cara 2: Siswa mengira bahwa waktu yang dibutuhkan Putra adalah 7 menit, kemudian menjumlahkan dengan waktu yang dibutuhkan Refa 15 menit sehingga menghasilkan jawaban 22 menit.

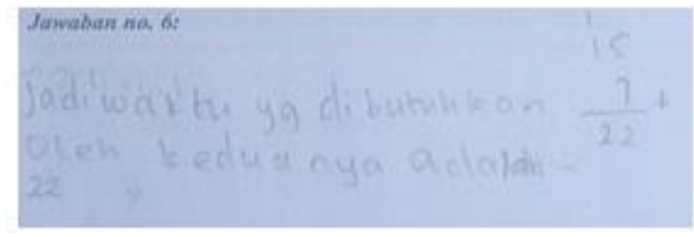

Gambar 15. Jawaban Siswa O
3) Cara 3: Menjawab asal menulis bilangan.

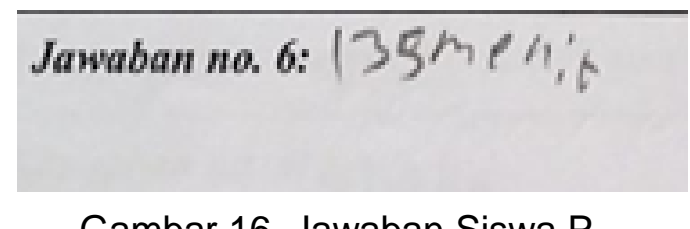

Gambar 16. Jawaban Siswa P

\section{e. Soal nomor 8}

Ibu menanam bunga di halaman rumah. Mula-mula tingginya $15 \mathrm{~cm}$. Setiap lima hari, tanaman ibu bertambah tnggi $2 \mathrm{~cm}$. Berapa tinggi tanaman ibu setelah satu bulan? (1 bulan $=30$ hari)

1) Cara 1: Mengubah masalah ke dalam gambar.

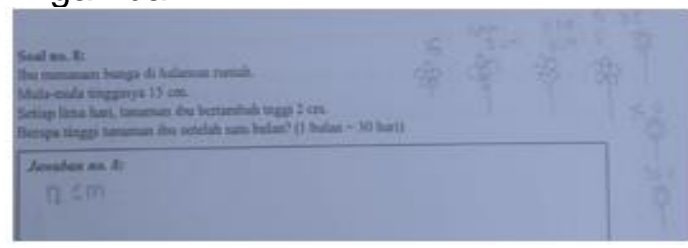

Gambar 17. Jawaban Siswa Q

2) Cara 2: Cara prosedural dengan operasi hitung.

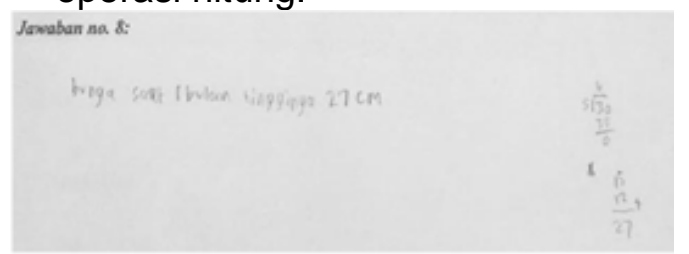

Gambar 18. Jawaban Siswa R

Berdasarkan temuan soal nomor 8, terdapat beberapa strategi untuk menyelesaikan soal cerita dengan materi pengukuran. Strategi pertama adalah dengan menggunakan bantuan gambar. Tahap yang dilakukan yaitu: (a) siswa membuat gambar untuk mewakili benda konkret; (b) membilang satu per satu baik berhitung maju maupun berhitung mundur; (c) menuliskan lambang bilangan berdasarkan hasil yang dia perloleh. Cara seperti ini masih dilakukan oleh siswa kelas IV yang berusia sekitar 10-11 tahun. Sementara itu, menurut teori kognitif Piaget siswa pada usia tersebut sudah memasuki tahap operasional konkret.

Strategi kedua adalah dengan menggunakan bantuan diagram. Siswa 
membuat garis bilangan kemudian membilang banyaknya bilangan yang dia lewati untuk mencapai akhir. Banyaknya loncatan tersebut sebagai jawaban dari siswa. Kemudian, siswa menuliskan lambang bilangan tersebut. Strategi ketiga adalah strategi menerjemahkan masalah ke dalam operasi hitung penjumlahan, pengurangan, perkalian, atau pembagian. Siswa seperti ini sudah mampu mebaca soal dengan baik, memahami soal dengan baik, dan mencari penyelesaiannya. Jika melihat pada strategi penyelesaian masalah menurut Polya berarti siswa ini sudah menyelesaikan masalah dengan baik. Jawaban yang diperoleh siswa kemudian dicek kembali.

Kesulitan yang dialami siswa dalam menyelesaikan soal cerita yaitu:

1) Kesulitan untuk memahami masalah dari segi kemampuan membaca pemahaman dan kalimat matematika. Salah satu faktor yang menyebabkan terjadinya hal demikian adalah penggunaan bahasa. Bahasa yang digunakan oleh siswa dalam kehidupan seharihari adalah bahasa ibu yaitu bahasa Sunda sehingga kerapkali siswa kurang mengerti dengan kata-kata yang ada pada soal seperti "lebih ringan", "lebih panjang", dan sebagainya. Selain itu, siswa mengalami kesulitan menerjemahkan bahasa soal ke kalimat matematika. Dengan demikian, kesulitan siswa dalam memecahkan soal cerita matematika tidak cukup didekati dengan pandangan ilmu matematika, tetapi memungkinkan dengan pandangan baru, yakni soal cerita sebagai sebuah wacana yang berkaitan dengan ilmu bahasa (Sumarwati, 2013).

2) Kesulitan untuk merepresentasikan masalah ke bentuk matematika dan gambar.

3) Kesulitan memahami konsep mengenai materi yang berkaitan dengan masalah. Meskipun materi yang diteskan sudah dipelajari oleh siswa, bisa saja siswa tidak memahami konsep dasar materi tersebut. Hal ini bisa terjadi karena ketika pembelajaran, tidak terjadi pembelajaran yang bermakna. Sebagaimana dikemukakan oleh Ausubel, terdapat tiga kebaikan belajar bermakna yaitu: (a) informasi yang dipelajari secara bermakna dapat diingat lebih lama karena masuk ke dalam memori jangka panjang; (b) informasi yang dipelajari secara bermakna memudahkan proses belajar berikutnya untuk materi pelajaran yang serupa; (c) bila unsur yang dipelajari tidak dapat lagi dipandang dari memori (dilupakan) maka akan terjadi subsumpsi obliteratif (subsumpsi yang telah rusak) sehingga materi yang diterima sukar diingat.

4) Kesulitan membangun strategi penyelesaian masalah terjadi pada beberapa siswa. Jika merujuk pada langkah penyelesaian masalah menurut Polya (1957) terdapat empat tahap penyelesaian yaitu: (a) memahami masalah; merencanakan penyelesaian masalah; (c) melaksanakan rencana penyelesaian masalah; dan (d) pemeriksaan kembali. Siswa tersebut sudah dapat memahami masalah, namun ia keliru ketika menyusun penyelesaian masalah.

Gangguan kognitif siswa terdapat pada satu siswa yang belum mampu membaca dengan baik. Kemampuan membaca merupakan dasar untuk menguasai berbagai bidang studi. Jika anak pada usia sekolah permulaan tidak segera memiliki kemampuan membaca, maka ia akan mengalami banyak kesulitan dalam mempelajari bidang studi pada kelas berikutnya (Abdurrahman, 2012). Setelah melakukan penyelidikan lebih lanjut terhadap guru di kelas tersebut, ternyata siswa yang dimaksud memang berada pada usia di bawah teman sekelasnya. Oleh sebab itu, jika ditinjau dari kemampuan kognitif Piaget sangat wajar apabila siswa tersebut belum mampu membaca dengan baik.

Hasil penelitian ini sesuai dengan penelitian Suganda (2014) 
bahwa kesulitan yang dialami siswa dalam menyelesaikan soal pemecahan masalah diduga berawal dari memahami masalah, merepresentasikan masalah ke dalam bentuk matematika maupun gambar dari suatu masalah, membangun penalaran dalam menyelesaikan soal pemecahan masalah, dan membangun strategi penyelesaian.

\section{SIMPULAN DAN SARAN}

Beberapa strategi yang
digunakan oleh siswa untuk
menyelesaikan soal cerita dengan
materi pengukuran adalah (1)
dengan menggunakan bantuan gambar, (2) strategi dengan menggunakan bantuan diagram, dan (3) strategi ketiga adalah strategi menerjemahkan masalah ke dalam operasi hitung penjumlahan, pengurangan, perkalian, atau pembagian.

Kesulitan yang dialami siswa dalam menyelesaikan soal cerita yaitu: (1) kesulitan untuk memahami masalah dari segi kemampuan membaca pemahaman dan kalimat matematika, (2) kesulitan untuk merepresentasikan masalah ke bentuk matematika dan gambar, (3) kesulitan memahami konsep mengenai materi yang berkaitan dengan masalah, (4) kesulitan membangun strategi penyelesaian masalah terjadi pada beberapa siswa, dan (5) gangguan kognitif siswa dimana terdapat satu siswa yang belum mampu membaca dengan baik.

Sebagai upaya untuk mengatasi kesulitan belajar yang dialami siswa dalam penyelesaian soal cerita, guru perlu mengidentifikasi letak kesulitan pada siswa. Selanjutnya, dapat diterapkan strategi act it out (memerankan masalah) dan make a drawing or diagram (membuat gambar atau diagram). Selain itu, diperlukan adanya pengayaan kepada siswa agar siswa mampu mengeksplorasi pola atau strategi untuk menyelesaikan soal cerita dengan strategi lain yang berbeda. Khusus siswa yang mengalami kesulitan dalam menyelesaikannya, perlu adanya identifikasi secara mendalam mengenai letak kesulitan siswa serta faktor yang memengaruhinya. Selain itu, bimbingan lebih lanjut dengan berbagai strategi dimulai dari strategi yang melibatkan benda konkret sampai abstrak sangat diperlukan.

\section{DAFTAR PUSTAKA}

Abdurrahman, M. (2012). Anak berkesulitan belajar: teori, diagnosis, dan remediasinya. Jakarta: Rineka Cipta.

Adjie, N. \& Maulana. (2006). Pemecahan masalah matematika. Bandung: UPI Press.

Alwasilah, C. (2009). Pokoknya kualitatif dasar-dasar merancang dan melakukan penelitian kualitatif. Jakarta: Pustaka Jaya.

Aydoğdu, M. Z. (2014). A research on geometry problem solving strategies used by elementary mathematics teacher candidate. Journal of Educational and Instructional Studies in The World, 7 (4): 53-62.

Cohen, L., Manion, L., and Marrison, K. (2007). Research in education sixth edition. Newyork: Routledge.

Creswell, J.W. (2013). Research design: Pendekatan kualitatif, kuantitatif, dan mixed. Terjemahan oleh Achmad Fawaid dan Rianayati 2013. Yogyakarta: Pustaka Pelajar.

Creswell, J.W. (2015). Riset pendidikan perencanaan, pelaksanaan, dan evaluasi riset kualitatif dan kuantitatif edisi kelima. Terjemahan oleh Soetjipto H.P. dan Soetjipto S.M. 2015. Yogyakarta: Pustaka Pelajar.

Crowe, S., dkk. (2011). The case study approach. BMC Medical Research Methodology: 11(1): 100.

Denzin, N.K. \& Lincoln, Y.S. (2009). Handbook of qualitative research. Terjemahan oleh Dariyatno, Fata B.S., Abi, \& Rinaldi, 2009. Yogyakarta: Pustaka Pelajar. 
Haylock, D. \& Anne C. (2013). Understanding mathematics for young children 4th Edition. London: SAGE.

Huda, N. \& Angel G. (2013). Analisis kesulitan siswa berdasarkan kemampuan pemahaman dalam menyelesaikan soal cerita pada materi kubus dan balok di kelas VIII SMP Negeri 30 Muaro Jambi. Prosiding Seminarta FMIPA Universitas Lampung. Lampung: UNILA.

Khabibah, S. \& Teguh W. (2016). Analisis kemampuan pemecahan masalah matematika siswa SMP berdasarkan langkah Polya. Diakses dari http://ejournal.umpwr.ac.id/index. php/ekuivalen/article/download/28 90/2715.

Mutaqin, E.J. (2013). analisis learning trajectory matematis dalam konsep perkalian bilangan cacah di kelas rendah sekolah dasar. Tesis tidak diterbitkan. Bandung: SPS UPI.

NAEP. (2011). The Nation's Report Card: Mathematic 2011. [Online]. Diakses dari https://nces.ed.gov/nationsreportc ard/pubs/main2011/2012458.asp $\mathrm{X}$

Naughton, G.M \& Hughes, P. (2009). Doing action research in early childhood studies: A step by step guide. USA: Open University Press.

Polya. (1957). How to solve it. Diakses dari

http://math.hawaii.edu/home/pdf/p utnam/PolyaHowToSolvelt.pdf.

Putra, N. \& Dwilestari, N. (2012). Penelitian kualitatif PAUD pendidikan anak usia dini. Jakarta: Raja Grafindo Persada.

Salimi, M. (2013). Analisis learning trajectory matematika dalam konsep penjumlahan pada siswa kelas rendah sekolah dasar. Tesis tidak diterbitkan. Bandung: SPS UPI.

Suganda, V. A. (2014). Analisis kesulitan dalam menyelesaikan soal pemecahan masalah dan sikap matematis siswa kelas $V$ sekolah dasar. (Tesis). Sekolah Pascasarjana, Universitas Pendidikan Indonesia, Bandung.

Sumarwati. (2013). Soal cerita dengan bahasa komunikatif untuk meningkatkan kualitas pembelajaran matematika sekolah dasar. Jurnal IImu Pendidikan. Jilid 1 Nomor 19.

Van De Walle, J. A. (2010). Elementary and middle school mathematics teaching developmentally. Boston: Pearson Edition.

Wahyudin. (2008). Pembelajaran dan model-model pembelajaran (pelengkap untuk meningkatkan kompetensi pedagogis para guru dan calon guru profesional. Bandung: UPI.

Alawiyah, Tuti. (2014). "Pembelajaran untuk Meningkatkan Kemampuan Komunikasi dan Pemecahan Masalah Matematik". Makalah Disajikan dalam Prosiding Seminar Nasional Pendidikan Matematika Program Pasca Sarjana STKIP Siliwangi Bandung1: 180-187.

Dewi, Sari K., Md Suarjana, dan Md Sumantri. (2014). "Penerapan Polya untuk Meningkatkan Hasil Belajar dalam Memecahkan Soal Cerita Matematika Siswa Kelas V". Jurnal Mimbar PGSD Universitas Pendidikan Ganesa $1(2)$.

Erliani, Eneng., Eli Rohmatullaeli, dan Nanang. (2011). "Pembelajaran untuk Meningkatkan Kemampuan Membuat Model Matematika dari Soal Cerita". Jurnal PTK Khusus(1):1-6.

Lestari, Nur I., Anton Noornia, dan Wardani Rahayu. (2010). "Analisis Kemampuan Siswa SD dalam 
Menerjemahkan Soal Cerita ke dalam Model Matematika dan Penyelesaiannya". Jurnal Matematika , Aplikasi dan Pembelajarannya 9 (1): 22-34.

Retna, Milda., Lailatul Mubarokah, dan Suhartatik. (2013). "Proses Berpikir Siswa dalam Menyelesaikan Soal Cerita Ditinjau Berdasarkan Kemampuan Matematika (The Student Thinking Process in Solving Math Story Problem)". Jurnal Pendidikan Matematika STKIP PGRI Sidoarjo 1 (2): 71-82.

White, Allan L. (2005). "Active Mathematics in Classrooms: Finding Out Why Children Make Mistakes -and Then Doing Something to Help Them". Square One 15(4): 15-19. 